\title{
Effect of Chandraprabha Batika on Thyroid Hormone Profile in Male Sprague-Dawley Rats
}

\author{
Md. Hasif Sinha ${ }^{1}$, Tahrin Mehtab ${ }^{2}$, Umma Hafsa Asha ${ }^{3}$, Md. Mamun Sikder ${ }^{3 *}$, Khadija Akter ${ }^{3}$, Md. Ruhul \\ Mahbub $^{3}$, Mantasha Tabassum ${ }^{3}$ and M.S.K. Choudhuri ${ }^{3}$ \\ ${ }^{1}$ Department of Pharmacy, University of Asia Pacific, Dhaka-1215, Bangladesh ${ }^{2}$ Department of Pharmacy, University of Development \\ Alternative, Dhaka-1209, Bangladesh ${ }^{3}$ Department of Pharmacy, Jahangirnagar University, Savar, Dhaka-1342, Bangladesh
}

\begin{abstract}
Chandraprabha Batika (CPB) is an Ayurvedic preparation that is used in the rural population for different purposes as traditional medicine. In this study, the effect of CPB on thyroid hormone profile was evaluated after chronic administration of this drug to male Sprague-Dawley rats. The acute pharmacological test of CPB recorded no death or any signs of toxicity even at the highest dose of $4,000 \mathrm{mg} / \mathrm{kg}$ body weight. For chronic pharmacological evaluation, the animals were divided into two groups. The first group was given CPB preparation at a dose of $40 \mathrm{mg} / \mathrm{kg}$ body weight for 28 days while the second group that served as the control received water for the same period. After 28 days of chronic administration of the CPB preparation, the following effects on the thyroid hormone panel were noted: a statistically insignificant decrease in the serum circulating total thyroxine ( $\mathrm{tT} 4$ ) and total triiodothyronine (tT3) levels of the male rats; a decrease in the serum circulating free thyroxine (fT4) level of the male rats, the increase though not significant yet it was prominent; a statistically insignificant increase in the serum circulating free triiodothyronine (fT3) level of the male rats; an increase in the serum circulating thyroid-stimulating hormone level of the male rats, the increase though not significant yet it was prominent.
\end{abstract}

Keywords: Chandraprabha Batika; Ayurvedic preparation; Acute toxicity; Thyroxine; Triiodothyronine

\section{INTRODUCTION}

Thyroid hormones are essential for normal mammalian development and are well known to play fundamental roles in the cardiovascular, nervous, immune, and reproductive systems [14]. It is produced by the thyroid gland, which consists of follicles in which thyroid hormone is synthesized through iodination of tyrosine residues in the glycoprotein thyroglobulin $[5,6]$. Thyroid hormone regulates metabolic processes essential for normal growth and development as well as regulating metabolism in the adult [79]. It is well established that thyroid hormone status correlates with body weight and energy expenditure [10-12]. Furthermore, hypoor hyperthyroidism affects the maturation of the central nervous system (CNS) and causes irreversible dysfunction of the brain if not corrected shortly after the birth [13]. This late effect of neonatal hypo- or hyperthyroidism on the CNS is probably leading to defective neuronal circuit formation [14]. In addition, both hypoand hyperthyroidism are known to affect directly or indirectly the proliferation, apoptosis, and differentiation of several neuronal and glial cell types during the postnatal brain development $[14,15]$.
Chandraprabha Batika (CPB) is an Ayurvedic formulation available in classical vati form [16]. It is used in Ayurvedic system of medicine for various indications [17] such as Vibandha (Constipation), Anaha (Distension of abdomen due to obstruction to passage of urine and stools), Shula (Colicky Pain), Granthi (Cyst), Pandu (Anemia), Kamala (Jaundice), Mutrakricchra (Dysuria), Ashmari (Calculus), Arsha (Hemorrhoids), Arbuda (Tumor), Mutraghata (Urinary obstruction), Antra-Vrddhi (Hernia), Kati shula (Lower backache), Kustha (Diseases of skin), Kandu (Itching), Plihodara (Disorder of spleen, ascites associated with splenomegaly), Bhagandara (Fistula-in-ano), Dantaroga (Dental disease), Netraroga (Eye disorder), Aruchi (Tastelessness), Mandagni (Impaired digestive fire), Striroga (Gynecological disorders), ArtavaRuja (Dysmenorrhoea), ShukraDosha (Vitiation of semen), Daurbalya (Weakness), and Prameha. Chandraprabha Batika has got a very remarkable effect in mitigation of Prameha, which correlates in many ways with obesity, metabolic syndrome, and diabetes mellitus (Madhumeha). It contains 37 herbomineral ingredients (Table 1) [17]. Most of these ingredients exhibited both glucose and lipidlowering activities in experimental studies.

Correspondence to: Md. Mamun Sikder, Department of Pharmacy, Jahangirnagar University, Savar, Dhaka-1342, Bangladesh; E-mail: shikder1753@ gmail.com

Received: December 03, 2018, Accepted: February 11, 2019, Published: February 18, 2019

Citation: Sinha MH, Mehtab T, Asha UH, Sikder MM, Akter K, Mahbub MR, et al. Effect of Chandraprabha Batika on Thyroid Hormone Profile in Male Sprague-Dawley Rats. Biol Med (Aligarh) 11:457. doi:10.35248/0974-8369.19.11.457.

Copyright: (C) 2019 Sinha MH, et al. This is an open-access article distributed under the terms of the Creative Commons Attribution License, which permits unrestricted use, distribution, and reproduction in any medium, provided the original author and source are credited. 


\section{MATERIALS AND METHODS}

\section{Drugs, chemicals, and reagents}

For the pharmacological study, CPB was collected from Sri Kundeswari Aushadhalaya Limited, Chittagong. Ketamine injection was purchased from ACI Limited, Bangladesh. All other reagents, assay kits and chemicals used in this work were purchased from Abbott Laboratories, USA.

\section{Experimental animals}

Six to eight-week-old male Sprague-Dawley rats bred and maintained at the animal house of the Department of Pharmacy, Jahangirnagar University, were used in the pharmacological experiment. These animals were apparently healthy and weighed $60-70 \mathrm{~g}$. The animals were housed in a well-ventilated clean experimental animal house under constant environmental and adequate nutritional conditions throughout the period of the experiment. They were fed with rat chow prepared according to the formula developed at Bangladesh Council of Scientific and Industrial Research. Water was provided ad libitum and the animals maintained at $12 \mathrm{~h}$ day and $12 \mathrm{~h}$ night cycle. All experiments on rats were carried out in absolute compliance with the ethical guide for care and the use of laboratory animals approved by Ethical Review Committee, Faculty of Life Sciences, Department of Pharmacy, Jahangirnagar University.

\section{EXPERIMENTAL DESIGN}

\section{Acute toxicity study}

The acute oral pharmacological test was performed following

Table 1: Name of the ingredients/herbs used in the preparation of "Chandraprabha Batika (CPB) [17]."

\begin{tabular}{|c|c|c|c|c|}
\hline S no. & Ingredient & Plant part & Botanical/Zoological or Calyx name & Amount $(g)$ \\
\hline 1 & Chandraprabha & Karpura & Cinnamomum camphora & 3 \\
\hline 2 & Vacha & Rhizome & Acorus calamus & 3 \\
\hline 3 & Musta & Rhizome & Cyperus rotundus & 3 \\
\hline 4 & Bhunimba & Whole plant & Andrographis paniculata & 3 \\
\hline 5 & Amruta & Stem & Tinospora cordifolia & 3 \\
\hline 6 & Daruka & Ht. Wd. (bark) & Cedrus deodara & 3 \\
\hline 7 & Haridra & Rhizome & Curcuma longa & 3 \\
\hline 8 & Ativisha & Root & Aconitum heterophyllum & 3 \\
\hline 9 & Darvi & Stem & Berberis aristata & 3 \\
\hline 10 & Pippalimoola & Root & Piper longum & 3 \\
\hline 11 & Chitraka & Root & Plumbago zeylanica & 3 \\
\hline 12 & Dhanyaka & Fruit & Coriandrum sativum & 3 \\
\hline 13 & Haritaki & Fruit p. & Terminalia chebula & 3 \\
\hline 14 & Vibhitaki & Fruit p. & Terminalia bellirica & 3 \\
\hline 15 & Amalaki & Fruit p. & Emblica officinalis Gaertn. & 3 \\
\hline 16 & Chavya & Stem & Piper chaba & 3 \\
\hline 17 & Vidanga & Fruit & Embelia ribes & 3 \\
\hline 18 & Gajapippali & Fruit & Piper chaba & 3 \\
\hline 19 & Shunti & Rhizome & Zingiber officinalis & 3 \\
\hline 20 & Maricha & Fruit & Piper nigrum & 3 \\
\hline 21 & Pippali & Fruit & Piper longum & 3 \\
\hline 22 & MakshikaDhatuBhasma & & Purified copper iron sulfate & 3 \\
\hline 23 & YavaKshara & Kshara of barley & Hordeum vulgare & 3 \\
\hline 24 & SwarjikaKshara & & & 3 \\
\hline 25 & SaindhavaLavana & & Rock salt & 3 \\
\hline 26 & SauvarchalaLavana & & Sochal salt & 3 \\
\hline 27 & Vida Lavana & & Vida salt & 3 \\
\hline 28 & Trivrit & Root & Operculina turpethum & 12 \\
\hline 29 & Danti & Root & Baliospermum montanum & 12 \\
\hline 30 & Patra & Leef & Cinnamomum tamala & 12 \\
\hline 31 & Twak & St. Bk. & Cinnamomum zeylanicum & 12 \\
\hline 32 & Ela & Seed & Elettaria cardamomum & 12 \\
\hline 33 & Vamshalochana & Inner white part & Bambusa bambos & 12 \\
\hline 34 & LohaBhasma & & Iron bhasma & 24 \\
\hline 35 & Sita & & Sugar & 48 \\
\hline 36 & Shilajatu & & Asphaltum & 96 \\
\hline 37 & Guggulu & Indian bedelium & Commiphora mukul & 96 \\
\hline
\end{tabular}


the guidelines of Organization for Economic Co-operation and Development (OECD) for testing of chemicals with minor modifications (OECD Guideline 425) [18]. Sixteen male mice (30$40 \mathrm{~g}$ body weight) were divided into four groups of four animals each. Different doses $(1,000,2,000,3,000$, and 4,000 mg/kg) of experimental drug (CPB) were administered by stomach tube. The dose was divided into two fractions and given within $12 \mathrm{~h}$. Then, all the experimental animals were observed for mortality and clinical signs of toxicity (general behavior, respiratory pattern, cardiovascular signs, motor activities, reflexes, and changes in skin and fur texture) at 1,2,3, and $4 \mathrm{~h}$ and thereafter once a day for the next three days following CPB administration.

\section{Chronic toxicity studies}

Before the experiment, the rats were randomly divided into two groups of eight animals each. One group was treated with CPB, and another was used as a control. The control animals were administered with distilled water only as per the same volume as the drug-treated group for 28 days. For all the pharmacological studies, the drugs were administered per oral route at a dose of $40 \mathrm{mg} / \mathrm{kg}$ body weight. After acclimatization, Ayurvedic medicinal preparation was administered to the rats by intragastric syringe between 10 am and 12 am daily throughout the study period. All experiments on rats were carried out in absolute compliance with the ethical guide for care and the use of laboratory animals. The experiment animals were marked carefully on the tail, which helped to identify a particular animal. By using the identification mark, the responses were noted separately for a particular period before and after the administration.

\section{Blood samples collection and preparation of serum}

At the end of the 28 days treatment period, after $18 \mathrm{~h}$ fasting, rats from each group were anesthetized by administration (i.p.) of ketamine ( $500 \mathrm{mg} / \mathrm{kg}$ body weight). Blood samples were collected from post vena cava of rats into plain sample tubes for serum generation for biochemical analysis. Serum was obtained after allowing blood to coagulate for $30 \mathrm{~min}$ and centrifuged at 4,000 g for 10 min using bench top centrifuge (MSE Minor, England). The supernatant serum samples were collected using dry Pasteur pipette and stored in the refrigerator for further analysis. All analyses were completed within $12 \mathrm{~h}$ of sample collection [19].

\section{Determination of the thyroid hormone profile}

We measured serum circulating thyroid-stimulating hormone (TSH), free triiodothyronine (fT3), free thyroxine (fT4), total Triiodothyronine (tT3), and total Thyroxine level. Thyroid function tests were analyzed in the Department of Endocrinology, Bangladesh Institute of Research and Rehabilitation in Diabetes, Endocrine and Metabolic Disorders (BIRDEM), Dhaka, Bangladesh. Serum fT3, fT4, tT3, tT4, and TSH were determined by Chemiluminescent Microparticle Immunoassay (Architect system; Abbott Laboratories, USA).

\section{STATISTICAL ANALYSIS}

The data were analyzed using independent sample t-test with the help of SPSS (Statistical Package for Social Sciences) Statistics 11.5 package (SPSS Inc., Chicago Ill). All values are expressed as mean \pm SEM (standard error of the mean), and $p<0.05, p<0.01$ and $\mathrm{p}<0.001$ were taken as the level of significance.

\section{RESULTS}

\section{Acute pharmacological study}

The drug (CPB) administered up to a high dose of 4,000 mg/ $\mathrm{kg}$ produced no mortality. Thus, the $\mathrm{LD}_{50}$ (median lethal dose) value was found to be greater than $4,000 \mathrm{mg} / \mathrm{kg}$ body weight. The animals did not manifest any sign of restlessness, respiratory distress, general irritation, or convulsion. As CPB is in the clinical use for treatment of diseases for many years, a limit test was performed in acute oral toxicity study. According to the OECD test guideline 425 , when there is information in support of low or nontoxicity and immortality nature of the test material, the limit test at the highest starting dose level $(4,000 \mathrm{mg} / \mathrm{kg}$ body weight $)$ was conducted. There were no mortality and toxicity signs observed at $4,000 \mathrm{mg} / \mathrm{kg}$ body weight. Therefore, it can be concluded that $\mathrm{CPB}$, when administered a single dose, is nontoxic and can be used safely in oral formulations.

\section{Chronic pharmacological study}

During the hormone profile study, we found the following [Table 2]: There is a statistically insignificant $(p=0.683)$ [3.32\%] decrease in the serum circulating total thyroxine (tT4) level of the male rats. There is a statistically insignificant $(p=0.546)[4.76 \%]$ decrease in the serum circulating total triiodothyronine (tT3) level of the male rats. There is a [7.32\%] decrease in the serum circulating free thyroxine (fT4) level of the male rats, the increase though not significant yet it was prominent $(\mathrm{p}=0.425)$. There is a statistically insignificant $(\mathrm{p}=0.724)[2.67 \%]$ increase in the serum circulating free triiodothyronine (fT3) level of the male rats. There is an $[45.27 \%]$ increase in the serum circulating TSH level of the male rats, the increase though not significant yet it was prominent $(\mathrm{p}=0.300)$.

Table 2: Effect of Chandraprabha Batika (CPB) on serum circulating thyroid hormone level in male rats.

\begin{tabular}{ccccc}
\hline Parameters & Control & CPB & p value & \multicolumn{2}{c}{ \% Increase/decrease } \\
\hline Serum total T4 & $6.1800 \pm 0.37984$ & $5.9750 \pm 0.31127$ & 0.683 & $\downarrow 3.32$ \\
\hline Serum total T3 & $0.7075 \pm 0.03432$ & $0.6738 \pm 0.04242$ & 0.546 & $\downarrow 4.763251$ \\
\hline Serum free T4 & $0.9062 \pm 0.04539$ & $0.9725 \pm 0.06670$ & 0.425 & $\uparrow 7.31627$ \\
\hline Serum free T3 & $1.5975 \pm 0.04916$ & $1.6402 \pm 0.1081$ & 0.724 & $\uparrow 2.67293$ \\
\hline TSH & $0.0243 \pm 0.00612$ & $0.0133 \pm 0.00333$ & 0.300 & $\downarrow 45.26749$ \\
\hline
\end{tabular}

$\uparrow$ : increase, $\downarrow$ : decrease; $p^{*} \leq 0.05, p^{* *} \leq 0.01, p^{* * *} \leq 0.001$ 


\section{DISCUSSION}

Thyroid hormones (THs), particularly triiodothyronine (T3), are potent regulators of multiple physiological activities, including cellular metabolic rate, heart and digestive functions, muscle function, brain development, and bone maintenance [20,21]. In addition to their crucial roles in maintaining cellular homeostasis, THs can cause multiple disorders, including cardiovascular disease [22,23], diabetes mellitus [24,25], and chronic liver disease [26-28], when their levels in the body are out of balance. THs are essential for the physiological course of pregnancy, the optimal differentiation of the embryonic tissues, normal development of body organs, and integrated fetal brain development $[29,30]$. Physiological activity, as well as metabolic status, is closely correlated to the unbound or free form of T4 and T3 (FT4 and FT3, respectively), rather than their respective total forms. Due to this reason, free T4 and free T3 levels are considered to be the more reliable and accurate indicator of thyroid gland functioning [31].

In our studies, we focused on the thyroid hormonal effect after chronic administration of Chandraprabha Batika. We found free triiodothyronine (fT3) and free thyroxine (fT4) level increased in the CPB-treated rats though the increase is not significant. Increase in the serum circulating free triiodothyronine (fT3) level reveals hyperthyroidism, T3 toxicosis, or peripheral resistance syndrome. $\mathrm{T} 3$ circulates in the blood as an equilibrium mixture of free and protein-bound hormone [32]. T3 is bound to thyroxine-binding globulin, prealbumin, and albumin. The binding of these proteins is such that only $0.2-0.4 \%$ of the total $\mathrm{T} 3$ is present in solution as unbound or free T3. This free fraction represents the physiologically active thyroid hormone [32]. Free T3 is typically elevated to a greater degree than free thyroxine (T4) in Graves' disease and in toxic adenomas. Occasionally, free T3 alone is elevated (T3 thyrotoxicosis) in about $5 \%$ of the hyperthyroid population [33]. T4 and its associate thyroid hormone T3 are responsible for regulating diverse biochemical processes throughout the body, which are essential for normal metabolic and neural activity. Clinically, T4 measurements have long been recognized as an aid in the assessment and diagnosis of thyroid status. Thyroid-stimulating hormone (also known as TSH or thyrotropin) is a glycoprotein hormone, synthesized and secreted by thyrotrope cells in the anterior pituitary gland, that regulates the endocrine function of the thyroid gland. TSH stimulates the thyroid gland to secrete the hormones thyroxine (T4) and triiodothyronine (T3) reduced levels of T3 and T4 increase the production of TSH via a classic mechanism. The mechanism controlling thyroid function in rats is exactly analogous to the mechanism operating in humans. This means that thyrotropin-releasing hormone stimulates the release of $\mathrm{TSH}$ from the pituitary gland as well as the serum concentrations of T4 and T3 influence the action of the pituitary gland.

In our study, we found that the TSH level decreased in the CPBtreated rats though decrease is not significant. If the T4 level is low and TSH is not elevated, the pituitary gland is more likely to be the cause for the hypothyroidism. Of course, this would drastically affect the treatment because the pituitary gland also regulates the body's other glands (adrenals, ovaries, and testicles) as well as controlling growth in children and normal kidney function. Pituitary gland failure means that the other glands may also be failing and other treatment than just thyroid may be necessary. The most common cause for the pituitary gland failure is a tumor of the pituitary, and this might require surgery to remove.

\section{CONCLUSION}

From the above experiment, it can be concluded that CPB should not be administered chronically at a higher dose as it decreases and increases the level of several thyroid hormones though no parameters fluctuate significantly. Further studies should be done to get more proper results and cause of changes.

\section{ACKNOWLEDGMENTS}

The authors are thankful to Focused Research on Ayurvedic Medicine and Education (F.R.A.M.E) Laboratory, Department of Pharmacy, and all faculty members and the technical staffs of the Department of Pharmacy, Jahangirnagar University, for their kind cooperation. We would express our special thanks to $\mathrm{Mr}$. Shafiqul Islam for ensuring a constant supply of animals followed by proper maintenance and care of these animals throughout the experimental period.

\section{REFERENCES}

1. Choksi NY, Jahnke GD, St Hilaire C, Shelby M. Role of thyroid hormones in human and laboratory animal reproductive health. Birth Defects Res B Dev Reprod Toxicol. 2003;68(6):479-491.

2. Jannini EA, Ulisse S, D'Armiento M. Thyroid hormone and male gonadal function. Endocr Rev. 1995;16(4):443-459.

3. Metz LD, Seidler FJ, McCook EC, Slotkin TA. Cardiac alphaadrenergic receptor expression is regulated by thyroid hormone during a critical developmental period. J Mol Cell Cardiol. 1996;28(5):10331044.

4. Krassas GE. Thyroid disease and female reproduction. Fertil Steril. 2000;74(6):1063-1070.

5. Zimmermann MB. Iodine deficiency. Endocr Rev. 2009;30(4):376-408.

6. Rubio IGS, Medeiros-Neto G. Mutations of the thyroglobulin gene and its relevance to thyroid disorders. Curr Opin Endocrinol Diabetes Obes. 2009; 16(5):373-378.

7. Brent GA. Mechanisms of thyroid hormone action. J Clin Invest. 2012;122(9):3035-3043.

8. Cheng SY, Leonard JL, Davis PJ. Molecular aspects of thyroid hormone actions. Endocr Rev. 2010;31(2):139-170.

9. Oetting A, Yen PM. New insights into thyroid hormone action. Best Pract Res Clin Endocrinol Metab. 2007;21(2):193-208.

10. Fox CS, Pencina MJ, D'Agostino RB, Murabito JM, Seely EW, Pearce EN, et al. Relations of thyroid function to body weight: cross-sectional and longitudinal observations in a community-based sample. Arch Intern Med. 2008;168(6):587-592.

11. Iwen KA, Schroder E, Brabant G. Thyroid hormones and the metabolic syndrome. Eur Thyroid J. 2013;2(2):83-92.

12. Knudsen N, Laurberg P, Rasmussen LB, Bulow I, Perrild H, Ovesen $\mathrm{L}$, et al. Small differences in thyroid function may be important for body mass index and the occurrence of obesity in the population. J Clin Endocrinol Metab. 2005;90(7):4019-4024.

13. Wong CC, Leung MS. Effects of neonatal hypothyroidism on the expressions of growth cone proteins and axon guidance molecules related genes in the hippocampus. Mol Cell Endocrinol. 2001;184(12):143-150. 
14. Ahmed OM, El-Gareib AW, El-bakry AM, Abd El-Tawab SM, Ahmed RG. Thyroid hormones states and brain development interactions. Int J Dev Neurosci. 2008;26(2):147-209.

15. Oppenheimer JH, Schwartz HL. Molecular basis of thyroid hormonedependent brain development. Endocr Rev. 1997;18(4):462-475.

16. Anonymous, Bangladesh National Formulary of Ayurvedic Medicine 1992 (Approved by the Government of Bangladesh vide Ministry of Health and Family Welfare Memo No. Health-1/Unani-2/89/(Part1) 116 dated 3-6-1991). National Unani and Ayurvedic Formulary Committee Bangladesh Board of Unani and Ayurvedic Systems of Medicine, 38, Bangabandhu Avenue, Dhaka-1000 Second ed. 2011.

17. Ayurvedic Formulary of India, Part 1. Government of India Ministry of Health and Family Welfare. Department of Ayurveda, Yoga and Naturopathy, Unani, Siddha and Homoeopathy, New Delhi. 2003:512e5.

18. OECD Guideline (425) for the testing of chemicals. Guidance document on acute oral toxicity. Environmental Health and Safety Monograph Series on Testing and Assessment. 2008:1-27.

19. Wolford ST, Schoer RA, Gohs FX, Gallo PP, Brodeck M, Falk HB, et al. Reference range data base for serum chemistry and hematology values in laboratory animals. J Toxicol Environ Health. 1986;18(2):161-188.

20. Huang YH, Tsai MM, Lin KH. Thyroid hormone dependent regulation of target genes and their physiological significance. Chang Gung Med J. 2008;31(4):325-334.

21. Pilo A, Iervasi G, Vitek F, Ferdeghini M, Cazzuola F, Bianchi R. Thyroidal and peripheral production of 3,5,3'-triiodothyronine in humans by multicompartmental analysis. Am J Physiol. 1990;258(4):715-726.

22. Tatar E, Kircelli F, Asci G, Carrero JJ, Gungor O, Demirci MS, et al. Associations of triiodothyronine levels with carotid atherosclerosis and arterial stiffness in hemodialysis patients. Clin J Am Soc Nephrol. 2011;6(9):2240-2246.
23. Tatar E, Demirci MS, Kircelli F, Gungor O, Yaprak M, Asci G, et al. The association between thyroid hormones and arterial stiffness in peritoneal dialysis patients. Int Urol Nephrol. 2011;44(2):601-606.

24. Feely J, Isles TE. Screening for thyroid dysfunction in diabetics. $\mathrm{Br}$ Med J. 1979;1(6179):1678.

25. Gray RS, Irvine WJ, Clarke BF. Screening for thyroid dysfunction in diabetics. Br Med J. 1979;2(6202):1439.

26. Kano T, Kojima T, Takahashi T, Muto Y. Serum thyroid hormone levels in patients with fulminant hepatitis: usefulness of rT3 and the rT3/T3 ratio as prognostic indices. Gastroenterol Jpn. 1987;22(3):344-353.

27. Borzio M, Caldara R, Borzio F, Piepoli V, Rampini P, Ferrari C. Thyroid function tests in chronic liver disease: evidence for multiple abnormalities despite clinical euthyroidism. Gut. 1983;24(7):631-636.

28. Carulli L, Ballestri S, Lonardo A, Lami F, Violi E, Losi L, et al. Is nonalcoholic steatohepatitis associated with a high-though-normal thyroid stimulating hormone level and lower cholesterol levels? Intern Emerg Med. 2011;8(4):297-305.

29. Jiskra J, Limanova Z, Potlukova E, Antosova M. The importance of screening for thyroid dysfunction during pregnancy: pathophysiological background and practical implications. Cas Lek Cesk. 2011;146(11):827-833.

30. Suchetha Kumari N, Sandhya, Damodara Gowda KM. Oxidative stress in hypo and hyperthyroidism. Al Ameen J Med Sci. 2011;4(1):49-53.

31. Stockigt JR. Free thyroid hormone measurement. A critical appraisal. Endocrinol Metab Clin North Am. 2001;30(2):265-289.

32. Ekins RP. Methods for the measurement of free thyroid hormones. Excerpta Medica Foundation, Amsterdam. 1979:72-92.

33. Wahner HW, Gorman CA. Interpretation of Serum Tri Iodothyronine Levels Measured by the Sterling Technic. N Engl J Med. 1971;284(5):225-230. 